\title{
Influence of urban forms on social sustainability of Indian cities
}

\author{
S. Hemani ${ }^{1}$, A. K. Das ${ }^{1}$ \& D. Rudlin ${ }^{2}$ \\ ${ }^{1}$ Indian Institute of Technology, Guwahati, India \\ ${ }^{2} U R B E D$, Manchester, UK
}

\begin{abstract}
Amidst huge pressures of development and accelerated urbanization faced by Indian cities, the social dimension, an important component of sustainable development, has largely been overlooked. Today, Indian cities have abandoned their pre-industrial socio-physical form and have become a patchwork of traditional, informal and newly planned areas. The former two are suffering from despair while the latter are new wealth enclaves that take-up a major share of urban growth. The country's GDP has grown by $9 \%$ but poverty has risen and social exclusion has become acute. The research explores the impact of these momentous changes on the future shape of Indian cities that are undergoing intense urbanisation. It asks; what is social sustainability in the Indian context and how do the urban forms perform in fostering it? Based on existing wide ranging secondary data, the research clarifies an understanding of social sustainability, its attributes and possible associations with urban form. Through empirical research of three distinct and prominent urban forms of Ahmedabad in Gujarat, the relationship between different aspects of urban form and social sustainability is tested. The evidence is further cross referenced with a comparative atlas based on different scaled maps for each case study area.
\end{abstract}

Keywords: sustainable development, social sustainability, urban form, social exclusion, urban divide, mapping.

\section{Introduction}

The social dimension is an important component of sustainable development but one that has been largely overlooked in Indian cities amidst huge development pressures and fast-forwarded urbanism. While sustainable development 
discourses to date have largely been limited to environmental and economic concerns, political endorsements with respect to social sustainability have mainly focused on improving the quality of life through infrastructural development, and poverty alleviation through slum upgradation programmes including provision of basic services. This narrow focus is at best ignoring and at worst destroying the social infrastructure that makes Indian Cities work, and indeed is fundamental to their character. The research therefore argues that a more comprehensive approach to social sustainability that looks at all its elements in an integrated manner is the need of the hour, given the rapid pace of change in the physical form of Indian cities. Uneven growth and increasing urban divide is creating a patchwork of formal 'Defensive City' (Fear of crime and a desire for exclusiveness is leading to new wealth enclaves linked by motorways and with privatised public spaces, fortress-like hotels, malls and office complexes), the traditional 'Forgotten City' (These are dense, mixed-use urban quarters, perceived as lacking in modern amenities and infrastructure but on the whole socially thriving places) and the informal 'Slum City' (These are built without permission, lacking all services and infrastructure and characterised by extreme poverty, ill health and deprivation). The former takes a major share of urban growth while the later two suffer from multiple deprivations. This urban spatial fragmentation not just a physical expression of income inequalities among Indian households but a social, cultural and economic divide that poses a danger to social stability and sustained economic growth (UN HABITAT [1]). While there is a growing awareness of these issues, urban policies and programmes lack clarity in knowledge and understanding of how the urban environment affects social sustainability, and the mechanisms to design and implement such inclusive strategies at the local level. The aim of the paper, therefore, is three-fold: (i) to understand the concept and role of social sustainability in the Indian development context, (ii) to test its relationship with urban forms and (iii) compare the evidence through a comparative atlas based on physical mapping of the case study neighbourhoods. The paper is laid out in following sections:

2. Social sustainability (SS): Based on secondary data this section inquires into three key areas:

2.1 The social dimension of sustainability: clarifies what is social sustainability: its importance, challenges, underlying concepts and theories.

2.2 The global perspectives and Indian Policy context: discusses how SS is perceived in the Indian context, establish its need and importance and review the current sustainable development policies in particular its social agendas.

2.3 Dimensions of social sustainability: discusses the key components of SS, describes ones that are more relevant to India's present urban context, and how this can be quantified.

3 Urban form: This section looks into the divided urban morphology of Indian cities and discusses in detail the three prominent urban forms mentioned earlier. It further sets out the key elements of urban forms relevant to Indian cities and discusses the claims made with respect to their influence on SS. 
4 Case study: This section forms the core of the research. It tests the different dependent SS components against more independent elements of urban form through detailed survey of the three case study areas in Ahmedabad. The results are used to cross reference the existing data sources and community surveys with a Comparative Atlas based on at various spatial scales. This Comparative Atlas is part of the wider 'Climax Cities' project (undertaken with URBED, Manchester) which is structured around international and multidisciplinary research on the various urban typologies in today's global cities. This paper should be treated as 'work in progress' and reflects only preliminary treatment of the subject. The first two sections are based on a review and critique of secondary documents on the subject while the third section comprises findings of a pilot study of three areas of Ahmedabad in Gujarat. These areas cannot and should not be typified or generalised for all similar forms as SS tends to be greatly influenced by individual behaviour and cultural patterns. However, this has been only tested through observations so far.

\section{Social sustainability (SS)}

This section does not aim to provide a standard definition for or operationalise SS, but attempts to identify its specific characteristics in the Indian urban context. It contributes to the ongoing debate on the subject and reviews the ways in which social sustainability has been perceived and presented so far. This in turn helps in developing a critical framework in order to analyse the relationship of SS with various urban forms.

\subsection{The social dimension of sustainability}

It is now in a general agreement that all the three dimensions of sustainability: social, economic and environmental, should be incorporated into a sustainable development policy context. However, initially environmental and economic issues dominated the sustainable development debates until late 1990s. Colantonio [2] argues that this is not only because sustainable development was born out of the synergy between 1960s environmental movement and 1970s 'basic needs', but also because its social aspects are difficult to measure/ quantify. He points out that SS is a complex and multifaceted concept which has often been studied through the lenses of separate disciplines and theoretical perspectives. For example, Barbier [3] states that SS must rest on social values such as culture, equity and social justice, Bremley et al. [4] focuses on equity and community, while Torjman [5] suggests poverty reduction, social investment and building of safe and caring communities as three priority directions. A plethora of social objectives, strategies and measurement instruments have been developed in social science but with little regard of the physical reality and sustainability perspective (Metzner [6]), resulting in difficulties to present the wealth of available knowledge in a way suitable for integration into sustainable development policies (Omann and Spangenberg [7]). Littig and Griessler [8] argue that these difficulties in conceptualising SS are also due to the fact that 
there is no clear differentiation between analytical, normative and political aspects thereof and that people may prioritise one over another. Although there is a lack of a bigger umbrella of a definitive normative meaning of SS that holds all the research work together, the quantum of theoretical research, measurement tools and policy considerations on the subject show a positive sign.

\subsection{The global perspectives and Indian policy context}

Today, development in fast-growing and urbanising countries such as India encounters socio-cultural challenges as poverty and inequalities are increasing in a worrisome manner. Rather than reducing deprivation and scarcity, the unbridled economic growth seems to multiply inequalities and reinforce social injustice by forever extending the limits of need. This in turn leads to an ever widening gap which is becoming less bearable. SS has gained considerable recognition and has become an integral part of government policies especially in Europe, Australia and Canada. However, in India, the sustainability discourse is characterised by ad hoc, fragmented and slow-moving policies on climate change, poverty, basic needs, etc., that do not keep pace with the massive unplanned and inequitable construction boom that is plaguing most Indian cities. Though an understanding of sustainable urban development is slowly building up, most of the policy context is focused on environmental concerns. The Government of India's more recent National Mission on Sustainable Habitat (NMSH), looks at the extension of the energy conservation building code in commercial buildings, better urban planning for modal shift to public transport, and urban waste management. Although these indicate positive interventions, parallel efforts relating to the amendment of byelaws, land use regulations, development controls, etc also need to be put in place for more holistic outcomes. While recognising general awareness on social dimensions of sustainability, NIUA's report on Sustainable Urban Form [9] also highlights ambiguous policy/regulatory setting, non-inclusive planning approach and the missing link between green and brown agendas as core constraints to sustainable urban planning, within a rapidly growing and changing urban environment.

\subsection{Dimensions of social sustainability}

Despite an apparent lack of consensus on the scope and meaning of SS, an extensive review of literature suggests that there are some broadly accepted common ingredients. Colantonio [2] puts forward a comprehensive list of key themes for the operationalisation of SS with basic needs and equity as its fundamental pillars. He argues that more intangible and less measurable emerging concepts such as identity, sense of place, quality of life and benefits of social networks are gaining importance. Based on critical evaluation of theoretical aspects of SS and current context of urban development in India, the paper focuses on four broadly inter-linked, but at times conflicting SS criteria namely social capital, social cohesion, social justice and social inclusion. After careful analysis, five key elements are selected for both the component groups that are further researched, analysed and tested against various independent 
elements of urban form. A brief explanation of each of the components are: Social justice and social inclusion: Both of these are strongly associated with equity, and imply enabling people to share in economic, environmental and social benefits, damages and costs as well as to participate in governance. The objective may focus on meeting basic needs, or on a more comprehensive redistribution of income (Baines and Morgan, IIED [10]). The UNDP [1994:20] has also identified poverty as the 'greatest threat to political stability, social cohesion and the environmental health of the planet'. In line with this, poverty reduction is a primary objective of sustainable development in India, but sound macro-micro economic programmes and more comprehensive social policies are yet to fully operationalize. Five key measures of social justice/inclusion are listed in Table 1 of which 'basic needs' and 'access to local services, facilities and opportunities' are discussed for the case study areas.

Table 1: $\quad$ Social sustainability measures.

\begin{tabular}{|c|c|}
\hline Social Justice/Social Inclusion & Social Capital/Social Cohesion \\
\hline $\begin{array}{c}\text { Basic needs (housing, water, sanitation, } \\
\text { drainage as well as education, skills, } \\
\text { livelihood. }\end{array}$ & $\begin{array}{c}\text { Pride of place/Attachment to the } \\
\text { locality }\end{array}$ \\
\hline Equitable income distribution & Social mixing/cultural unity \\
\hline Access to local facilities and opportunities & Social interaction \\
\hline Health and safety & Safety/trust \\
\hline Decision and participation & Stability/Demographic change \\
\hline
\end{tabular}

Social capital and social cohesion: The role of social capital and social cohesion in promoting sustainable development has received increased attention in both development theory and practice in recent years. Social capital refers to 'features of social organisation such as networks, norms and trust that facilitate co-ordination/co-operation for mutual benefit' (Putnam et al. [11]) and is a fundamental component of many social institutions which influence the governance and collective decision-making of an organisation (Baines and Morgan, IIED [10]). Social cohesion, on the other hand, is variously described as the 'affective bond between citizens' (Chipkin and Ngqulunga [12]), 'promoting harmony and a sense of community' (Colletta et al. [13]) and capacity of a society to ensure the welfare of all its members, minimising disparities and avoiding polarisation (CDCS [14]). Social cohesion is also an independent or intervening variable in relation to peace building and conflict prevention (King et al. [15]). The following table lists five key measures of Social Capital/Cohesion.

\section{Urban form}

Urban form can be defined as spatial pattern of human activities at a certain point in time (Anderson et al. [16]). This spatial DNA of cities plays an important role in sustainable development by securing liveability and flexibility of urban environments that house a constantly transforming society. However, over recent 
decades, urban landscapes have undergone a significant change in the way they are experienced and envisioned. The importance of place has diminished as global flows of people, ideas, capital, mass media and other products have accelerated. The walkable city has evolved into less navigable sprawls of urban landscapes, full of brusque ruptures and fragmented urban forms. The concentration on the overwhelming need for new housing, industry and infrastructure has led to an irreparable break in the centuries' long evolution of the urban fabric of cities. Rushing into the modern age in a few short decades has left little time for Indian cities to restructure their pre-industrial physical form. The difficulty for the urban planners in India lies not just with the rate or even vast scale of urbanisation, but with the lack of appropriate understanding and development mechanisms of how built environments affect sustainability, especially its social dimension. This often results in a temptation to reach for western models to prescribe for essentially different socio-cultural situations (Miao [17]). Moreover, there is also an increasingly intense debate in policy and practice about the extent to which the adaptation of the physical form of cities and the way people live and move in them can improve sustainability (Jenks and Jones [18]). In the Western context, the concept of Sustainable Urban Form have long been embodied in planning policy and urban design theories such as Smart Growth, New Urbanism, Urban Intensification and Compact City. All these emphasize on the importance of generating diversity, mix of uses, transport choices and walkability, permeability and street grids as well as compact forms and higher densities. Nicholson-Lord [19] argues that the new orthodoxy and obsession with compact cities risk great planning disaster - a new era of town cramping which by ignoring human relations with nature will do nothing to secure the long term sustainability of the city. There is also a difference amongst authors about the preferred type of detailed city structure, viz. linear, dispersed centralised and polynuclated urban forms, or some variation of the grid. However, at the moment, there is little hard evidence in terms of urban sustainability to unequivocally support one theoretical urban structure over another. Moreover, it is equally important to understand that urban form and sustainability is more complex than mere style or a rigid set of rules. Rather, there are principles that are essential for people to live together in large cities in harmony with nature. There is not just one, but many physical models that can satisfy these principles (Jenks et al. [20]). To understand urban form better and study its relationship with SS, it is necessary to comprehend what constitutes its basic elements. While the urban form of a city can be measured through various aspects, for the purpose of the study, five key elements considered relevant to the Indian context have been detailed in Table 2. These different elements may not be relevant at certain spatial scales or may vary in the way they are perceived.

All the above-mentioned elements of urban form seem to influence social sustainability to a certain extent; however, literature review suggest competing claims that are rarely supported by empirical evidence mainly because it is difficult to measure more qualitative issues of SS. Of all the elements of urban form, density is one that has received most attention in research and policy 
Table 2: $\quad$ Urban form measures.

\begin{tabular}{|c|c|c|c|}
\hline URBAN FORM MEASURES & $\mathbf{C}$ & $\mathbf{N}$ & $\mathbf{H}$ \\
\hline DENSITY & * & $*$ & \\
\hline $\mathrm{Ppl} / \mathrm{hec}$ and dwelling units/hec at city and neighbourhood level & & & * \\
\hline \multicolumn{4}{|l|}{ Ppl./dwelling unit and avg family size/average house size } \\
\hline \multicolumn{4}{|l|}{ SHAPE AND SIZE } \\
\hline Growth pattern & $*$ & $*$ & * \\
\hline Structure (linear, gridded, polycentric or multicentric, hybrid) & * & & \\
\hline Height and Massing & $*$ & * & * \\
\hline \multicolumn{4}{|l|}{ DISTRIBUTION OF USES, ACTIVITIES AND OPEN SPACES } \\
\hline Location and distance from major city level activities and uses & * & & \\
\hline Mix of use (resi, commercial, industrial, institutional, etc) & & * & \\
\hline Predominant ground floor activity and uses & & * & * \\
\hline No. of active frontages & & $*$ & \\
\hline \multicolumn{4}{|l|}{ MOVEMENT, ACCESSIBILITY AND CONNECTIONS } \\
\hline Street network and permeability & * & & \\
\hline Street hierarchy (as per use and width of the streets) & $*$ & * & \\
\hline Modes of transport (bus, 3 wheeler, 2 wheeler, bicycle) and parking & * & * & $*$ \\
\hline Walkability aspect & & * & \\
\hline Observations such as hawkers, plantation, lighting, cleanliness, etc & & $*$ & \\
\hline \multicolumn{4}{|l|}{ HOUSING TYPE AND MIX } \\
\hline Type of house (flat, row house, tenement, bungalow, hut, live/work) & & * & $*$ \\
\hline Percentage mix of house types & & * & \\
\hline Setback from street and fencing/gate & & & $*$ \\
\hline Type and size of private open space (frontyard, backyard, courtyard, & & * & $*$ \\
\hline
\end{tabular}

context, as it has the potential to impact on all the dimensions of SS (Bremley et al. [4]). Claims have been made that higher densities make access to services and facilities easier and economically viable (Haughton and Hunter [21]) contributes positively to social equity (Burton [22]), social interaction and vitality (Talen [23]), sense of community (Nasar and Julian [24]) as well as lower levels of social segregation (Jenks and Jones [18]). There are also many alternative arguments vis-à-vis very high densities such as decline of community (Wirth [25]), and weakening of social ties (Freeman [26]). Bremley et al. [4] through their empirical research conclude that for most aspects of SS, lower density suburbs appear best. More recent research conducted by NIUA [9] also concludes that middle to lower density neighbourhoods demonstrate greater SS than high density areas. In the Indian urban context where apartments are becoming more popular, SS is not just dependent on the built form, but other influencing factors such as cultural-regional biases, socio-economic mix of residents, etc also need to be considered. Hence, exploring different urban forms and studying their SS capacities could provide better insights on how these co-relate in the Indian context. 


\section{Case study: comparing the forgotten, informal and formal cities within Ahmedabad}

\subsection{Introduction}

The city of Ahmedabad founded in 1411 AD as a walled city on the eastern bank of the river Sabarmati, is now one of the prominent urban centres and the financial hub of the State of Gujarat in western India. With a population of 7.2 million and density of $890 \mathrm{ppl} / \mathrm{sqkm}$, and steeped in history, Ahmedabad is a fast-growing centre for education, information technology and scientific institutions. With major developments such as SEZs, IT corridors, integrated townships, gated communities, as well as BRTs, the city has made news for its superior infrastructure and good quality of life. The real estate scene boasts of a mix of "product categories" - residential apartments, bungalows, row houses, plotted schemes, farm houses, and commercial as well as retail spaces concentrated in the western limits of the city. However, Unni [27] points out that the current model of urbanisation is promoting inequity, with less space, resources and higher costs for the urban poor, as compared to increasing facilitates and amenities for the urban upper /elite classes. This divide is also obvious in the city morphology. Two prominent settlement forms, the historic "inner" (walled city) and the contemporary "informal" (slum city) have provided both economic and residential opportunities for the urban poor who can ill afford the more prosperous and modern real estate. However, these two settlement forms are experiencing severe challenges contributing to increasing social, cultural and economic exclusion. The research argues that both these settlement forms represent traditional urbanism and support numerous sustainable development principles. Over time, the cultural richness, spatial vitality and economic dynamism of these settlements will enrich not just the local inhabitants but impact the wider city as whole. Moreover, the paper maintains that achieving sustainable urban development is likely to prove impossible if this divide between the three urban forms in the city is allowed to persist and grow. The research, thus, focuses on three neighbourhoods based on their urban form and socio-economic characteristics and compares how each of these forms performs in fostering SS. A brief description of each is given in Table 3.

\subsection{Theoretical framework}

The theoretical framework for the study is set out in figure 1 and aims to examine different SS and urban form parameters at three spatial scales namely city, neighbourhood and household level. The observations and survey data are further cross-referenced through a comparative atlas for the three case study areas based on scaled maps; the context of the entire city within $10 \mathrm{~km}$ radius, the trellis of connections within $5 \mathrm{~km}$ radius, the public realm within $1 \mathrm{~km}$ radius, the urban form within $500 \mathrm{~km}$ radius, the detailed urban tissue within $100 \mathrm{~m}$ radius and finally generic representative component within $50 \mathrm{~m}$ radius. These maps will be used to develop statistical evidence at a later stage. 
Table 3: $\quad$ Case study details.

\begin{tabular}{|c|c|c|c|}
\hline $\begin{array}{l}\text { Case Study } \\
\text { Areas }\end{array}$ & $\begin{array}{l}\text { 1. Forgotten } \\
\text { walled city: } \\
\text { Desai ni pol }\end{array}$ & $\begin{array}{l}\text { 2. Informal slum city: } \\
\text { Kanthiyawadi Vas, } \\
\text { Pravin-Guptanagar }\end{array}$ & $\begin{array}{c}\text { 3. Formal } \\
\text { defensive city: } \\
\text { Shaligram-3 }\end{array}$ \\
\hline Ward & Khadia & Vasna & $\begin{array}{l}\text { Prahladnagar } \\
\text { Garden }\end{array}$ \\
\hline Zone & East & West & West \\
\hline No. of units & 95, (resi. 85) & 517 & 74, (Occupied 62) \\
\hline Rooms/unit & $3-5$ & $1-2$ & $4-6$ \\
\hline Avg. family size & 5 & 6 & 3 \\
\hline Density & $433 \mathrm{ppl} /$ hectare & $2585 \mathrm{ppl} /$ hectare & $321 \mathrm{ppl} /$ hectare \\
\hline $\begin{array}{c}\text { Socio-economic } \\
\text { background }\end{array}$ & $\begin{array}{l}\text { Lower/upper } \\
\text { middle class }\end{array}$ & $\mathrm{SC} / \mathrm{ST} / \mathrm{OBC}$ & Higher class \\
\hline $\begin{array}{c}\text { Typical } \\
\text { residential unit } \\
\text { type } \\
\end{array}$ & $\begin{array}{c}3 \text { storey narrow } \\
\text { linear row house } \\
\text { with courtyard } \\
\end{array}$ & $\begin{array}{c}\text { Spontaneous settlement } \\
\text { usually } 1 \text { to } 2 \text { storey } \\
\text { row house }\end{array}$ & Flats and duplexes \\
\hline \multicolumn{4}{|c|}{$\begin{array}{l}\text { A "pol" is a small residential unit consisting of a single street with a group of houses } \\
\text { usually protected by a massive gate at the entrance and often inhabited by people of } \\
\text { the same trade or clan. Although spatial distribution based on the rigid division of } \\
\text { caste and religion is not as prevalent as in the past, people belonging to the same } \\
\text { religion tend to live in close proximity exhibiting a strong sense of belonging fostered } \\
\text { by the fact that they live in physically identifiable clusters (Mehta [287). }\end{array}$} \\
\hline \multicolumn{4}{|c|}{$\begin{array}{l}\text { PNGN is one of the four slums in a cluster of about 5,000 slum households. This } \\
\text { cluster was established after the } 1973 \text { flooding in the river Sabarmati. With an area of } \\
\text { approximately 80,000 sq.mt., PNGN has a population of 7,416 person with largest } \\
\text { Kanthyawadi community. The slums started expanding because of the influx of } \\
\text { relatives of the residents of PNGN and its surrounding settlements. Different } \\
\text { communities took up residence, with each community living in their respective } \\
\text { 'chawl'(Vas) or lane. The Slum Networking Project (SNP), in partnership with } \\
\text { government, NGO's, private donors and community was aimed at not only } \\
\text { infrastructural improvement but overall community development (Joshi et al. [29]). }\end{array}$} \\
\hline \multicolumn{4}{|c|}{$\begin{array}{l}\text { Shaligram-3 is a new high income gated luxury apartment complex built in 2004. It is } \\
\text { located in Prahlad Nagar area, an upcoming commercial centre outside AMC limits to } \\
\text { the west of the city. It consists of 74, two to four bedroom apartments, each with } \\
\text { attached servant's quarter. In recent years the area has seen massive development with } \\
\text { high-end commercial buildings and offices, shopping malls and clubs. The occupants } \\
\text { are heterogeneous majorly migrated from other cities due to employment opportunities } \\
\text { or new businesses. }\end{array}$} \\
\hline
\end{tabular}

\subsection{Methodology}

The urban form and its social attributes are understood through a series of site visits involving mapping, measurement, verification, photo/video documentation, residents' focussed group interviews as well as discussions with academicians, government officials, conservationists, social workers and other stakeholders. Offsite work includes reviewing secondary data, digitizing various scaled maps from Google Earth, encoding field data and final analysis of the three spatial patterns at different scales. Qualitative analysis conducted through 


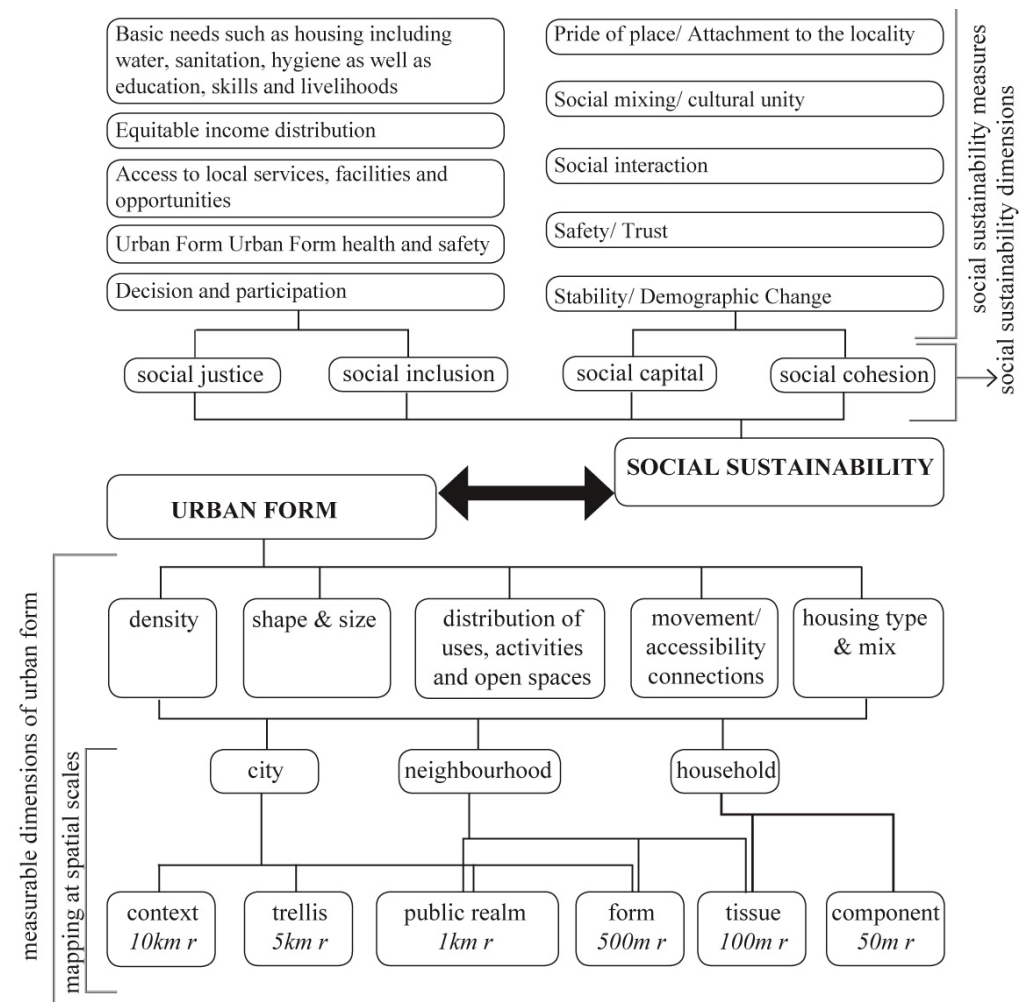

Figure 1: Theoretical framework.

observation, while detailed quantitative measurements through a Comparative Atlas and regression analysis forms the next stage of this research.

\subsection{Key observations}

Key observations are shown in Table 4.

\section{Conclusions}

Although the fundamentals of urban form remains universal in every location, any area will develop in response to local circumstances such as class structures, economic systems, perceptions of safety, topography, ownership and governance until it reaches its climax form where everything may be in balance and the urban ecosystem appropriately suited to its local conditions as it may ever do. In each location, a slightly different combination of these factors leads to completely different urban typology and social patterns. The comparative study of the three case studies provided good insight on the relationship of urban form and SS. It was observed that two key factors, (i) individual behaviour and 
Table 4: $\quad$ Key observations.

\begin{tabular}{|c|}
\hline Key Observations and Survey Analysis on Social Sustainability Measures \\
\hline Note: Case Study 1(CS-1): Forgotten city; Case Study 2 (CS-2): Informal city; Case \\
Study 3 (CS-3): Formal city \\
\hline 1. Basic needs such as housing including water, sanitation, drainage as well as \\
education, skills and livelihood.
\end{tabular}

All the three case studies had a neighbourhood park. CS:-1: The private open space in terms of courtyard and terraces was sufficient. The otla (veranda) blurred the publicprivate boundaries and was a key space for interaction. Despite compact form and lack of large/green public open spaces, the residents did not find the need for more open space. The pol was not just a street for movement and access but a social space, a representation of the collective domain. The overlap of activities (social, community activities, play space, movement) resulted in an intense use of the pol-street. CS-2: Private open space was absent or took the form of a terrace or 'osri' (semi covered front area) of the 1-2 room dwelling unit. Scarce indoor living spaces partly seemed to compel the residents to use the outdoor spaces for interaction. However, the residents did express the need for parks, safe play areas for children; (single community square usually around a religious building used by the entire settlement, at times lead to some conflict) and a community hall/plot to hold weddings and other community functions. The main street with shops and evening outdoor market also facilitated interaction. CS3: Private open spaces were in the form of balconies. The entrance foyer, library, club house and a garden with children's play area provided sufficient community spaces.

There were also a number of city clubs and shopping malls for recreation in the vicinity.

\section{Pride of place/Attachment to the locality}

CS-1: The residents showed very high attachment to the locality, and were keenly interested and took pride in the upkeep of the pol, especially after the restoration of heritage buildings and conservation efforts from the AMC. CS-2: The feeling of pride among the residents for their locality was low as the area is termed as 'slum'. However, the attachment to the locality was very high. Although people have climbed up the informal property ladder and moved between houses in different slums, they have remained in the Vasna area. However the residents are constantly under threat of eviction as the tenure is semi-legal. CS-3: The residents took pride of their locality; however, their attachment to the place was not as strong as in the other two areas as most of the residents saw this as a temporary stage. 
Table 4: $\quad$ Continued.

\begin{tabular}{|c|}
\hline \\
\hline $\begin{array}{l}\text { Social mixing and cultural unity was found to be good in all the three case study areas. } \\
\text { However, it was observed that for social unity there needs to be a commonality that } \\
\text { binds people together, in CS-1 and CS-2 it was caste/religion and non-differentiation } \\
\text { of area of residence by wealth, while in the case of CS-3 it was class, similar lifestyle } \\
\text { choices and economic status. In CS-1, although social cohesion of medieval times is } \\
\text { not evident today, there was still a strong sense of belonging, fostered by the fact that } \\
\text { the residents live in physically identifiable clusters Mehta [28]. Same was observed in } \\
\text { CS-2, where social networks in the form of informal associations were based on origin/ } \\
\text { regional affinities and caste/religious ties Joshi [29]. There was little interaction and } \\
\text { social mixing among different community clusters until institutional efforts were made. } \\
\text { Festivals and religious functions also created opportunities for social mixing, bonding } \\
\text { and unity. }\end{array}$ \\
\hline 6. Social interaction \\
\hline $\begin{array}{l}\text { CS-1 and CS-2: The inhabitants of both the areas shared a very close co-existence } \\
\text { even on a day-to-day level. A continuous social interaction occurred between members } \\
\text { of different households throughout the day; doors were left open, with free } \\
\text { accessibility to all homes to all members of the community can be observed even } \\
\text { today. The public-private boundaries were blurred and constantly negotiated depending } \\
\text { on use and function throughout the day. CS-3: There was a good level of social } \\
\text { interaction among the residents. The common areas provided spaces for this; however } \\
\text { unlike the other two areas, interaction was not constant and throughout the day as } \\
\text { personal domain and privacy was accorded high consideration. However groups of } \\
\text { maids, children, the elderly and women were seen chatting and interacting on most } \\
\text { evening. }\end{array}$ \\
\hline \\
\hline $\begin{array}{l}\text { All the three case study areas found their neighbourhoods very safe and trust among } \\
\text { the residents was high. It is interesting to note that though the new formal city } \\
\text { represents a defensive form through huge building complexes and high security, the } \\
\text { historic pol street too consists of a group of houses protected by a massive gate at the } \\
\text { entrance (the word 'pol' is derived from the Sanskrit word 'patroli' which simply } \\
\text { means door or entrance). The residents of SC-1 had a desire to erect gates to restrict } \\
\text { passing traffic and prevent cows from entering the pol. Gates, grills and fences were } \\
\text { also observed among the community clusters of CS-2. However, given the extrovert } \\
\text { character of the morphology and nature of the society, there was a very high natural } \\
\text { surveillance in place and gates were only for protection during the night. }\end{array}$ \\
\hline 8. Stability/Demographic change \\
\hline $\begin{array}{l}\text { CS-1: The pol had a stable population, a majority of them residents since the past } 40 \\
\text { years or more, with a very keen desire to continue to live in the same area. CS-2: A } \\
\text { majority of the population was stable, with a very strong sense of ownership. Rented } \\
\text { properties housed migrant population from rural areas who expressed that they would } \\
\text { like to continue staying in the same area. CS-3: Represented urban to urban migration, } \\
\text { with less stability than CS-1 and 2. People residing in this area have come due to } \\
\text { business/job opportunities and were likely to move back to their home city or aspire to } \\
\text { move into yet another bigger house or take up better job opportunity. }\end{array}$ \\
\hline
\end{tabular}


aspirations and (ii) cultural patterns and adaptability, strongly influence SS of a particular settlement form. It was also interesting to note: urban forms, at spatial scales of household and neighbourhood levels had more influence on social cohesion/ capital, while those at city level involving political and government interferences had more influence on the selected elements of social justice/inclusion. At the city level, the urban morphology might seem fragmented, but at the neighbourhood level, it emerged as a strong, cohesive social and spatial unit. While SS in its holistic and integrated sense remains absent in urban design and policy context in India, such an approach is also only an emerging component of sustainable development in the more developed world. There is yet no agreed definition for SS; its measurement is problematic; and it is highly context-dependent, which causes difficulties when attempting to balance it not only at policy, design and implementation levels but also amalgamating it across different disciplines and spatial levels. Nevertheless, this should not prevent us from exploring the potential unity of SS at all these echelons for inclusive and sustainable growth. India should move away from taking economic drivers as initial givens in its environmental mitigation responses and address social, environmental and economic objectives together right from the start. With a focus on all aspects of SS, this paper calls for an integrated approach to sustainable development, building on the overall concepts of planning policy and design processes across the development paradigm. The next is to articulate the SS objective and mandating it within the policy framework. For this, the government should develop goals (in relation to the economic, social and environmental assets) as well as standards (at various spatial scales and different development stages).

\section{References}

[1] UN-HABITAT, State of the World's Cities: Bridging the Urban Divide 2010/2011, Earthscan: UK and USA, pp 52-100, 2008.

[2] Colantonio, A., Measuring Social Sustainability: Best Practice from Urban Renewal in the EU, Working Paper Series 2007/01, EIBURS, pp3, 2007.

[3] Barbier E.B., The concept of sustainable economic development, Environmental Conservation Vol. 14, (2), pp. 101-110, 1987.

[4] Bremley, G., Brown, C., Dempsey, N., Power, S. \& Watkins, D., Social Acceptability (Chapter 5). Dimensions of the Sustainable City, eds. Jenks, M., Jones, C., Springer, pp: 105-128, 2010.

[5] Torjman, S., Social Dimension of Sustainable Development. Paper prepared for the Commissioner of Environment and Sustainable Development at the Office of Auditor General, Caledon Institute of Social Policy, pp1-11, 2000.

[6] Metzner, A., Caring Capacity and Carrying Capacity - A Social Science Perspective, Paper presented at the INES 2000 Conference: Challenges for Science and Engineering in the 21st Century, Stockholm, 2000.

[7] Omann, I., \& Spangenberg, J. H., Assessing Social Sustainability: The Social Dimension of Sustainability in a Socio-Economic Scenario, 
presented at the 7th Biennial Conference of the International Society for Ecological Economics, Sousse (Tunisia), 2002.

[8] Littig, B., Grießler, E., Social sustainability: a catchword between political pragmatism \& social theory, Int. J. Sustainable Development, 8(1/2), pp.72, 2005.

[9] National Institute of Urban Affairs (NIUA), Sustainable Urban Form for Indian Cities, Research Study Series No:112, March 2011.

[10] Baines, J. \& Morgan, B., Sustainability Appraisal: A Social Perspective (Chapter 5) IIED code G02181, http://pubs.iied.org/pdfs/G02181.pdf

[11] Putnam, R., Leonardi, R., Nanetti, Y., Making democracy work: civic traditions in modern Italy. Princeton, NJ: Princeton University Press, pp. 35, 1993.

[12] Chipkin, I. and Ngqulunga, B., Friends and family: social cohesion in South Africa. Journal of Southern African studies, 34 (1), pp. 61-76, 2008.

[13] Colletta, N.J., Lim, T.G. and Kelles-Viitanen, A., eds. Social cohesion and conflict prevention in Asia: managing diversity through development. Washington, DC: The World Bank, 2001.

[14] European Committee for Social Cohesion (CDCS), A new strategy for Social Cohesion, Council of Europe, pp-3, 2004.

[15] King, E., Samii, C. \& Snilstveit, B., Interventions to promote social cohesion in sub-Saharan Africa. 3ie Synthetic Review 002. Delhi: International Initiative for Impact Evaluation (3ie), 2010.

[16] Anderson, W. P., Kanaroglou, P. S. and Miller, E. J., Urban form, energy and the environment: a review of issues, evidence and policy, Urban Studies, 33(1), pp. 7-35, 1996.

[17] Miao, P. ed., Public Places in Asia Pacific Cities: Current Issues and Strategies; Kluwer Academic Publishers, Netherlands, 2001.

[18] Jenks, M., Jones, C. (eds). Dimensions of the Sustainable City, Springer, 2010.

[19] Nicholson-Lord, D., Green Cities - And Why We Need Them, NEF Pocketbook 9, New Economics Foundation, London, pp-2, 2003.

[20] Jenks, $\mathrm{M}$ and Burton, $\mathrm{E}$ and Williams, $\mathrm{K}$ (ed). The compact city: A sustainable urban form? E\&FN Spon, London, 1996.

[21] Haughton, G. \& Hunter, C. Sustainable Cities, Jessica Kingsley Publishers, London, 1994.

[22] Burton, E., The compact city: Just or just compact? A preliminary analysis, Urban Studies, 37(11), 2000.

[23] Talen, E., Sense of community and neighbourhood form: an assessment of the social doctrine of new urbanism, Urban Studies, 36(8), 1999.

[24] Nasar, J \& Julian, D., The psychological sense of community in the neighbourhood, Journal of the American Planning Association, 61, 1995.

[25] Wirth, L., Urbanism a way of life, American Journal of Sociology, 44(124), 1938.

[26] Freeman Freeman, L., The effects of sprawl on neighbourhood social ties, Journal of the American Planning Association, 67(1) 6977, 2001. 
[27] Unni, J., The Unorganised Sector and Urban Poverty: Issues of Livelihood, (Chapter 4), India: Urban Poverty Report 2009, http://www.indg.in/socialsector/urban-poverty-alleviation/india urban poverty report 2009.pdf

[28] Mehta, P., Integrated Urban Design - Inner City, Vadodara, Master of Design (Urban) thesis, University of Canberra, 2001.

[29] Joshi, R, Shah, P, Nazareth, K, Mahadevia, D, From Basic Services Delivery to Policy Advocacy - Community Mobilisation in PravinnagarGuptanagar, Ahmedabad, Working Paper 6, Centre for Urban Equity, Ahmedabad, 2010. 